\title{
Juvenile Justice (Care and Protection of Children) Act 2015: A Review
}

Dr. Smita Agarwal ${ }^{\dagger}$ and Nishant Kumar ${ }^{\top}$

\section{Abstract}

The aim of this article is to look into the provisions of the newly amended Juvenile Justice Act. The central question which this article looks at whether the article is comprehensive enough to eliminate the possibilities of crime by juveniles as it is based on principle of reformation and rehabilitation of children who are otherwise presumed to be innocent not to commit a crime. It also tries to see if the intention of juveniles involved in crimes can be differentiated from their social surroundings that can help to punish the perpetuators in the former while thinking of remedial measures in the latter.

Key words: Juvenile, Age Cap, Rehabilitative Justice, Juvenile Justice Act, India

\footnotetext{
${ }^{+}$Assistant Professor, Department of Political Science, University of Delhi, Email: Smita.agarwal03@gmail.com 'Assistant Professor, Department of Political Science, Dyal Singh College, University of Delhi, Email: nishantdu@hotmail.com

(C) 2016 Agarwal and Kumar. This is an Open Access article distributed under the terms of the Creative Commons Attribution License (http://creativecommons.org/licenses/by/2.0), which permits unrestricted use, distribution, and reproduction in any medium, provided the original work is properly cited.
} 


\section{Introduction}

Juvenile delinquency is not new. However it has become a cause of concern in India with the release of Crime in India Report, 2014, which shows that from 2003 to 2014 crimes committed by children have increased from $1 \%$ to $1.2 \%$. In fact, children of the age group 16-18 years were responsible for $66 \%$ of crimes committed by all children in 2013 reflecting an increase of ten percent points from 2003 records (Crimes in India, 2014: 128-129). The recently passed Juvenile Justice (Care and Protection of Children) Act (henceforth, JJ Act) by the Indian Parliament on the 22 December 2015 aims to amend the existing Juvenile Justice (Care and Protection of Children) Act of 2000 by attempting to examine the mental faculties of the child who commits a crime and not focus on the age. The larger question is about the rationale behind keeping 18 years as cut-off mark for adulthood when there is a looming debate about whether human brain is completely developed until that age. ${ }^{1}$ Also, is the Act comprehensive enough to eliminate the possibilities of juvenile crime by laying stress on complete rehabilitation of juvenile delinquents by providing psychological help and enabling social conditions that can assimilate them in society? In order to understand these issues, it is important to situate the Act in the context in which it was produced and its possible ramifications.

This Act was passed in the background of the release of one of the convicts of the infamous Delhi rape case of December $2012,{ }^{2}$ on the

\footnotetext{
1 Preeti Jacob, Assistant Professor, Department of Child and Adolescent Psychiatry at the National Institute of Mental Health and Neuroscience, Bengaluru, says that there is no valid, magic age which can work as a marker to define individuals as juveniles or adults. "Neuroscience has shown that the brain continues to develop well into the third decade of life. The 18 years cut-off is in itself an arbitrary number" [Rao and Krishnan, 2015]

2 On the night of 16 December 2012, a paramedical student was brutally gang-raped by six men on a moving bus in Delhi. The incident shook the nation for the torture inflicted upon the girl which eventually led to her death. The gruesome case outraged the collective conscience of the people which was reflected in protest demonstrations all over the country on the issue of
}

pretext that he was below 18 years of age when the crime was committed and as according to existing laws had to be treated as a juvenile. There were strong protests from several quarters of the civil society against the release of the convict. The government introduced the Act in order to respond directly to the doubts raised about the competence of the existing law as a deterrent and, at the same time, to review for the possibilities of redefining the content and scope of laws concerning juveniles. ${ }^{3}$ While debating the Act in the Parliament, Mrs. Maneka Gandhi, the Minister of Women and Child Development, remarked that it was a 'comprehensive Act' which included issues regarding adoption and foster care as well (Rajya Sabha Debates, 22 December 2015: 60). She acknowledged that the main contention was about the 'proposed reduction from 18 to 16 years for the purpose of allowing a juvenile to go to jail, if it is perceived that he committed a heinous crime' (Rajya Sabha Debates, 22 December 2015: 6061). To clarify the purpose of the clause, she gives two examples. In one case, there is a child whose drunken father beats his mother everyday and inflicts pain on him and his siblings by stubbing cigarettes on their body. One day the child hits back at the father which leads to his death. In another case, few boys of 16 years of age drug a seven-year-old girl and kidnap her. She is kept in a field for three days

safety of women in the national capital (Bhattacharyya, 2013, 2015; Durham, 2015; Rao, 2014; Singh, 2013).

3 This was the second important legislation to be passed in the aftermath of the Delhi rape case of 2012. Soon after the incident, the Government appointed a high power three member committee under former late Chief Justice of India, J. S. Verma to recommend amendments to the criminal laws for quicker trials and enhanced punishment for criminals accused of committing sexual assaults on women. Following some of the recommendations of the committee, the government passed The Criminal Law (Amendment) Act, 2013 in March 2013. This new law expanded the definition of rape to include any non-consensual penetration of sexual nature and made provision for death penalty for criminals accused of rape. This new law also initiated significant changes to the punishments on crimes like trafficking, acid attack, sexual harassment, voyeurism, and stalking (The Gazette of India, 2 April 2013; also, Bhattacharyya, 2013, 2015). 
and is repeatedly raped by these young boys. Unlike the existing laws where the accused in both cases would be let off as juveniles, the recommended clause, Maneka Gandhi claimed, would punish the perpetuators of the crime in the second case as the act of violence was intentional and curated (Rajya Sabha Debates, 22 December 2015: 61). However, the pressure of public expectation was explicit during her speech as she constantly referred to the reactions on the news of release of the convict in Delhi rape case. Her utterances like 'the whole country is in sombre mood.... The parents of the girl are watching us...' shows the inherent conflict whereby it was aimed both at satisfying public demand and also while adhering to United Nations Convention on Child Rights ascertain reformative justice (Rajya Sabha Debates, 22 December 2015: 63-66).

\section{Highlights of the Act}

Age Cap: Continuing with the age cap of juvenile at 18 years, this act introduces a new category of 16-18 years who could be convicted as adults in case of heinous crimes (offences with punishment of 7 years or more under Indian Penal Code) [JJ Act, Sec. 2(33)]. ${ }^{4}$

Boards \& Committees: The 1986 Act established Juvenile Welfare Boards and Juvenile Court. The 2000 Act skipped the establishment of a special court but the Juvenile Welfare Boards were carried on and Child Welfare Committees were established. However, the 2015 Act carries the provision for 3 members on the Boards (Metropolitan or judicial Magistrate +2 Social Workers) (JJ Act, Sec. 4); establishes Child Welfare Committee (JJ Act, Sec. 27); and revives the Children's Court for every district (The Commissions for the Protection of Child Rights Act 2005, Sec. 25; Protection of Children Against Sexual Offences Act 2012, Sec. 28). In the former two bodies, at

\footnotetext{
${ }^{4}$ It is important to note here that different countries of the world have different age cap as of when a child can be treated as an adult in case of serious and heinous crimes. For example, in England it is 17 years; in South Africa and France it is 16 years; in Canada and Germany the age cap is at 14 years, and in the USA, it is at 13 years (Institute for Policy Research, 2015).
}

least one woman member is mandatory which was also present in the 1986 and 2000 Act.

Adoption: Establishment for State Adoption Resource Agency and Central Adoption Resource Agency which monitors, regulates, make rules, etc. in regards to adoption of children (JJ Act, Sec. 67-68). It further lays down criteria for prospective parents adoption which was absent in earlier Acts. This clause would help in speeding the adoption process. Monthly visit by Child Welfare Committees to foster family has been added.

Child Care Institutions: Unlike the Act of 2000, the registration of Child Care Institutions has been made mandatory (JJ Act, Sec. 41).

\section{Analysis of the New Act}

Carrying forward the spirit of reformation and rehabilitation of juvenile justice, the Act continues with the segregation between 'children in need of care and protection' and 'children in conflict with law' (JJ Act, Sec. 2). While the former includes children who are in adverse conditions, requiring state support to become responsible citizens, the later are those children who have committed crimes.

The National Crime Records statistics show that though there was an increase in juvenile crimes, not all these crimes were committed 'intentionally'. For example, the report indicates that majority of the children accused of crime belonged to financially backward families with an annual income of not more than $₹ 25,000$ and the crimes they were involved in were theft, burglary, etc. (Crime in India, 2014: 132). Thus, it is held that if such children are provided with healthy atmosphere, they can grow to become responsible citizens. As a result, the Act includes a clause for adoption of such children by allowing intercountry adoption in case foster parents are not available in the country (JJ Act, Sec. 36). In order to stop child trafficking, the Act ensures stricter offences for people who are involved in supplying drugs to children. In fact, the punishment is harsher in this case compared to physical assault (JJ Act, Sec. 76-78). Further, in cases where families surrender their children 
due to adverse conditions, the Act has increased the time period to take them back before they can be given for adoption from one month to two months as compared to what was in the original Bill that was tabled in Lok Sabha in August, 2014 [J Act, Sec. 36(3)]. This change, however, is based on the assumption that family atmosphere is the most conducive atmosphere for a child's development. It does not take into consideration the fact that $80.2 \%$ of criminal acts, as reported by National Crimes Records, are committed by children who are with family (Crimes in India, 2014: 132). If it is so, rather than overemphasising on the family as a mechanical unit to counter crime by children, the Act should have aimed at family as a repository of emotional and holistic development of child. This would require state intervention in providing accessibility to resources to families where it is lacking, and on the other hand to help in developing emotional bonds within family through counseling. Efforts like these can help in reducing crime among children and instilling in them a sense of right and wrong which can be a deterrent in compelling circumstances. Therefore, the ambit of Child Welfare Committees could have been enlarged to ensure such interventions as and when required. Also, the law in its current form looks retrogressive as the financial/continued support which was available to children from time to time until the age of 21 after they had left children's home has been reduced to one time support. This unfortunately puts them back to the vicious cycle of poverty and destitution, which, as warned by the National Crimes Records, is one of the main reasons for increasing crime rate among juveniles.

Under the 'children in conflict with law' category, the government taking into consideration the differential treatment between adult and child that has been enshrined in the United Nations Convention on Rights of Children (UNCRC), continues to define children under same benchmark of 18 years but with differential treatment of children between 16-18 years who are accused of being involved in heinous crimes. The Standing Committee of the Parliament observed that this clause violated the UNCRC as it created a sub-category within the definition of juvenile. The UNCRC states that signatory countries should treat every child under the age of 18 years in the same manner and not try them as adults. The Act of 2000 was enacted to implement the UNCRC guidelines in the Indian context. The amendment to the act in the current form categorizes crimes committed by juveniles into following: (i) heinous offences [those with minimum punishment of seven years of imprisonment under Indian Penal Code (IPC) or any other law], (ii) serious offences (three to seven years of imprisonment), and (iii) petty offences (below three years of imprisonment) (JJ Act, Sec. 7). It is maintained that a juvenile cannot be given life imprisonment without the possibility of release or death penalty. Under the new Act, a juvenile in conflict with law can be required to spend a maximum of three years in a special home or fit facility. However, a juvenile in the age group of $16-18$ years may be tried as adults if the crime falls in the category of heinous offence, irrespective of date of apprehension. Also, a juvenile between 16-18 years of age who has committed a serious offence and apprehended after the age of 21 years, may be tried as an adult. By inserting this clause 'irrespective of apprehension,' this Act tries to plug the holes of the earlier Act that had let go off those child criminals who had intentionally committed a crime taking advantage of age. Further, the Juvenile Justice Boards (JJB) will conduct preliminary assessment over that child's mental and physical capacity to commit such crime [JJ Act, Sec. 14(3)] and if the Board gives him a clean chit, he can still escape the criminal liability (JJ Act, Sec. 17). In case it is deemed to be tried as an adult, the Board would transfer the case to the Children's Court [JJ Act, Sec. 18(3)]. Even at this stage, the Children's Court may refuse its trial as an adult if it thinks so [JJ Act, Sec 19(i)]. However, if the trial is conducted and the person is proved guilty, he will be sent to a safe place till he attains the age of 21 and then he would be transferred to a jail [JJ Act, Sec. 19(3)]. But if the Children's Court found some reformative changes in the child, it may release 
the child at the age of 21 [JJ Act, Sec. 20(2)]. During the child's stay in the place of safety, reformative services such as counseling, etc. shall be provided. The Court shall ensure periodic follow up reports by District Child Protection Units (JJ Act, Sec. 40).

\section{Conclusion}

It is explicit that the Act continues (a) the spirit of reformation and rehabilitation of juveniles by institutionalizing child care; (b) meticulously distinguishes between adult and child trials and brings in 'intentions' of juveniles that had earlier let them free. Despite this care the Act violates article 14 of the Indian constitution by treating two people accused of same offence differently. This needs to be understood in the context of intentions of accused that uses these safeguards for their advantage. This Act first describes the age and then investigates into his/her mental capacity which should be opposite. There are cases in which persons of age 25 years do not possess an adult mind and there are children of age below 16 years who possess a matured mind with much experience of the practical world (Rao and Krishnan, 2015). The surroundings in which the child has been nurtured matters a lot. The Act fails to further the objective of providing a holistic environment to deter crimes among them by limiting it to the mechanical category of family only.

\section{References}

Bhattacharyya, Rituparna (2015).

Understanding the Spatialities of Sexual Assault against Indian Women in India, Journal Gender, Place and Culture, 22(9), 1340-1356, DOI: 10.1080/0966369X.2014.969684

Bhattacharyya, Rituparna (2013). Criminal Law (Amendment) Act, 2013: Will It Ensure Women's Safety in Public Spaces?, Journal Space and Culture, India, 1(1), 13-27, DOI: http://dx.doi.org/10.20896/saci.v1i1.11

Durham, Meenakshi Gigi (2015). Scene of the Crime: News Discourse of Rape in India and the Geopolitics of Sexual Assault, Feminist Media
Studies, 15(2), 175-191,

DOI:10.1080/14680777.2014.930061

Institute for Policy Research (2015). PRS

Legislative Research: Juvenile Justice (Care and Protection of Children) Bill, 2014, available at http://www.prsindia.org/uploads/media/Juveni le\%20Justice/Legislative

\%20Brief\%20Juvenile\%20Justice\%20Bill.pdf (last accessed February 10, 2016).

National Crime Records Bureau (2014). Crime in India: 2014, available at

http://ncrb.nic.in/index.htm (last accessed February 22, 2016).

Rajya Sabha Debates (2015, December 22). Debate on Juvenile Justice Bill, available at http://164.100.47.5/ new deb ate/237/22122015/Fullday.pdf (last accessed February 18, 2016).

Rao, Mohit M. and Vidya Krishnan (2015, December 27). Neuroscience and the Juvenile Legislation. The Hindu, available at http://www.thehindu.com/opinion/neuroscien ce-and-the-juvenile-legislation/article 8032028.ece (last accessed February 16, 2016).

Rao, Shakuntala (2014). Covering Rape in Shame Culture: Studying Journalism Ethics in India's New Television News Media, 29 (3), 153167, DOI: 10.1080/08900523.2014.918497

Singh, S. (2013, September 13). Delhi Gang Rape: Case Diary. The Times of India, available at http://timesofindia. indiatimes.com/india/Delhi-gang-rape-Casediary/articleshow/22455125.cms (last accessed February 15, 2016).

The Gazette of India (2016, January 1). Juvenile Justice (Care and Protection of Children) Act, 2015, available at http://wcd.nic.in/sites/default/files/JJ\%20Act,\% 202015\%20_0.pdf (last accessed February 20, 2016).

The Gazette of India (2013, April 2). The Criminal Law (Amendment) Act, 2013, available at http://india code.nic.in/acts-inpdf/132013.pdf (last accessed February 13, 2016 